\title{
DEPRECIATED REPLACEMENT COST: IMPROVING THE METHOD THROUGH A VARIANT BASED ON THREE CORNERSTONES
}

\author{
Sergio Copiello, PhD \\ Department of Design and Planning \\ IUAV University of Venice \\ e-mail: copiello@iuav.it \\ Pietro Bonifaci, PhD \\ Department of Design and Planning \\ IUAV University of Venice \\ e-mail:pbonifaci@iuav.it
}

Abstract

Within the scope of real estate appraisal, the Depreciated Replacement Cost method is mostly seen as a solution of last resort, when no other option is available. Nonetheless, it is ever more useful in addressing various estimation needs. In its basic formulation, the method suffers from several simplifications that lead to rather rough results. Here we try to go beyond these limits. To this end, we propose a variant based on the following three cornerstones. The first is the partition of the replacement cost into its fundamental components, at least according to three cost items: building structure, finishes, and installations. The second cornerstone is the formulation of different depreciation curves for each of the cost items mentioned above, by processing distinct data on useful life and residual life. Finally, the third cornerstone is represented by the definition of a complex depreciation function to take into account both the original useful life of the construction and its lengthening due to partial or full refurbishments.

Key words: depreciated replacement cost, replacement value, real estate appraisal, deterioration, obsolescence.

JEL Classification: $C 13, R 30$.

Citation: Copiello S., Bonifaci P., 2018, Depreciated Replacement Cost: Improving the Method Through a Variant Based on Three Cornerstones, Real Estate Management and Valuation, vol. 26, no. 2, pp. 33-47.

DOI: $10.2478 /$ remav-2018-0014

\section{Introduction}

Real estate appraisal and property investment valuation have been strongly developed during the post-Second World War decades, due to the spread of urban settlements and human-related land uses. According to the financial glossary edited by MORGENSON, HARVEY (2002), Real estate appraisal may be broadly defined as "An estimate of the value of property using various methods". Besides, WYATT (2013) identifies Property valuation as "the process of forming an opinion of value-inexchange under certain assumptions" (p. 49). The two disciplines are strictly related, and both are intimately related to economic science, sharing its fundamentals: demand, supply, marginal utility, and market equilibrium, all of which are basic concepts that contribute to structuring their methodological framework. The well-known International Valuation Standards provide the principles needed to solve the issues of appraisal and valuation. The framework mainly relies on different bases of value. The market value basis refers to "the most probable price that" a property would achieve "in a hypothetical exchange in a free and open market" (IvSC 2013, No. 27 a). Bases other than market 
value refer to, for instance, the appreciation expressed by a particular investor (investment value) or a special purchaser (special value, synergistic value) (IVSC 2016). Moreover, the framework includes three estimation approaches: the market approach, which relates to the analysis of the transaction prices; the cost approach, which recalls the expenses to be incurred in order to build real estate goods; and the income approach, which develops through the capitalization process. The combination of bases and approaches gives rise to a double entry table encompassing all the estimation methods (Tab. 1).

The method discussed here - Depreciated Replacement Cost (DRC) - falls under the framework of both the replacement value basis and the cost approach. The former refers to the "total cost of replacing an asset", considering "allowances for professional fees and ... factors related to construction of a replacement asset" (IVSC 2016, No. 90.1). The latter relies on "the economic principle that a buyer will pay no more for an asset than the cost to obtain an asset of equal utility, whether by purchase or by construction" (IVSC 2013, No. 62). A widely accepted definition states that DRC should be identified as "The current cost of replacing an asset with its modern equivalent asset", taking into account the "deductions for physical deterioration and all relevant forms of obsolescence and optimization" (RICS 2013, p. 6).

Valuation bases, approaches, and methods

Table 1

\begin{tabular}{|c|c|c|c|}
\hline & Market approach & Cost approach & Income approach \\
\hline \multirow[t]{2}{*}{$\begin{array}{l}\text { Market value } \\
\text { basis }\end{array}$} & $\begin{array}{l}\text { Sale price } \\
\text { comparison }\end{array}$ & \multirow[t]{2}{*}{$\begin{array}{l}\text { Construction cost } \\
\text { comparison }\end{array}$} & \multirow[t]{2}{*}{$\begin{array}{l}\text { Direct (income) } \\
\text { capitalization }\end{array}$} \\
\hline & $\begin{array}{l}\text { Hedonic price model } \\
\text { and mass appraisal }\end{array}$ & & \\
\hline \multirow{3}{*}{$\begin{array}{l}\text { Bases other than } \\
\text { market value }\end{array}$} & & \multirow{3}{*}{$\begin{array}{l}\text { Depreciated } \\
\text { Replacement Cost }\end{array}$} & Yield capitalization \\
\hline & & & $\begin{array}{l}\text { Discounted cash- } \\
\text { flow analysis }\end{array}$ \\
\hline & & & $\begin{array}{l}\text { Profit capitalization } \\
\text { Residual method }\end{array}$ \\
\hline
\end{tabular}

Source: own study based on IVSC 2016.

\subsection{Introductory glossary}

Before discussing the method and the proposed variant, a few definitions are needed, since several meaning inflections can be found in literature.

1) Property: a composite asset including both a construction - or, more broadly, a building compound - and the underlying land plot; therefore, the term refers jointly to the physical fabric of a building and to the site hosting it.

2) Construction cost: the cost to be incurred to erect a building, including the technical cost of construction, overhead expenses, and profit. In turn, the technical cost of construction is the sum of the following cost items: raw materials; labor; goods and services needed to arrange and manage the construction site (COPIELLO 2016).

3) Land value: the value of urban land parcels suitable to be exploited for building purposes according to both their physical condition and legal status.

4) Depreciation: the decline in value that a construction shows over time; more precisely, here we rely on the definition coined by Law in 2004 (quoted in CROSBY et al. 2011, p. 9), namely, "the rate of decline in [...] value of an asset [...] over time relative to the asset [...] valued as new with contemporary specification."

5) Deterioration: a cause of depreciation meant as a continuous physical process due to the use of a good.

6) Obsolescence: other cause of depreciation meant as a non-linear, irregular, and discontinuous socio-economical process, according to the definition provided by HOESLI, MACGREGOR (2000), who identifies the obsolescence as "a decline in utility not directly linked to physical usage" (p. 158). 


\section{Depreciated Replacement Cost method}

\subsection{Method's rationale}

The DRC rationale assumes that real properties usually differ in terms of a remarkable number of characteristics, such as typology, building materials, location, neighborhood amenities, and so forth. When it comes to considering market-related aspects, a fundamental distinction pertains to the availability of comparable transactions. Some kinds of properties are commonly traded in highly active markets, with hundreds or thousands of transactions over a reference time span; other properties belong to very rarefied markets, namely, niches characterized by just a few exchanges - if any - in a decade or more. The former situation suggests using the market comparison approach. The latter condition entails the need to make use of alternative estimation procedures. Out of these, the DRC method plays a role when others are unworkable, thus representing a method of last resort (WYATT 2013). Nonetheless, it has recently regained importance due to the property market recession, which caused a slowdown in sales in many sub-markets (COPIELLO et al. 2017).

\subsection{Methodological process}

The method proceeds through five stages (Fig. 1) leading to the appraisal of the replacement value $(R v)$ of a property.

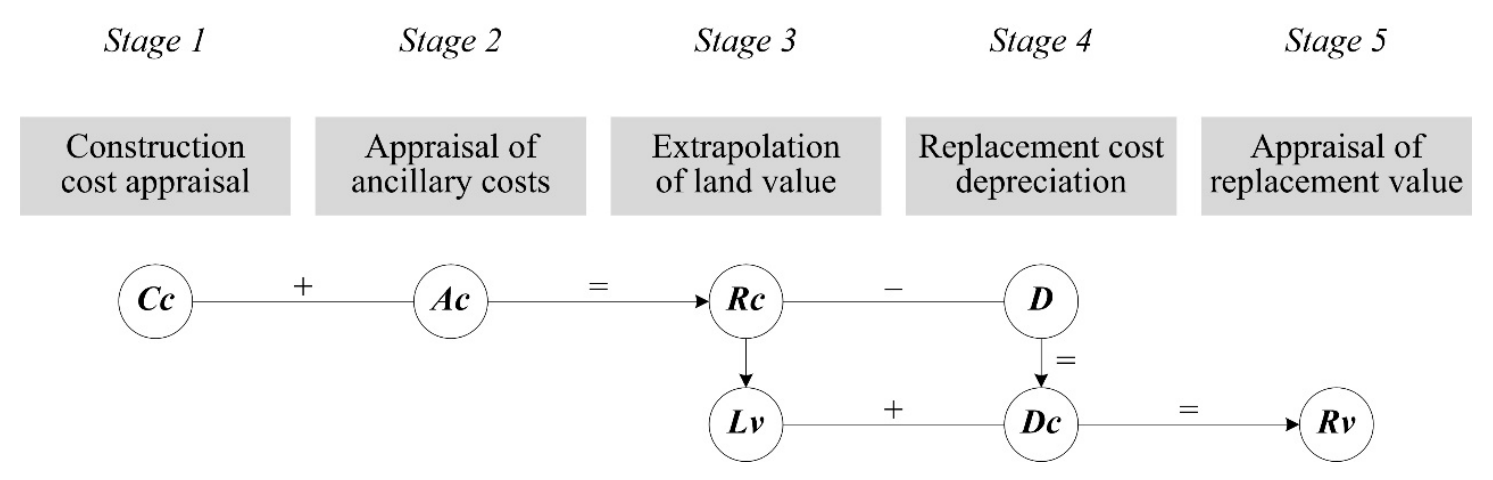

Fig. 1. Five-stage methodological process. Source: own study.

The first phase focuses on the appraisal of the construction cost $(C c)$ of a reference building, which should provide the same utility level as the analyzed one. Among the information sources, worth mentioning are the inventories of building typologies and related construction costs, which are suitable for concise estimates. See, for instance, the construction cost handbooks for South-eastern Asia (LANGDON \& SEAH 2016) and for Europe, the United States, and Japan (DAVIS LANGDON \& EVEREST 2000), or the price lists provided by several consultant organizations, such as the Dutch Association of Cost Engineers (DUTCH ASSOCIATION OF COST ENGINEERS 2015) and the Milan Board of Engineers and Architects in Italy (MILAN BOARD OF ENGINEERS AND ARCHITECTS 2014).

The second phase is meant to consider the ancillary costs $(A c)$. The main items are as follows: professional allowances paid for design activities and construction site management, planning fees owed to local authorities as a premise to get the building permission, debt service, that is to say, interest due on borrowed capital, and promoter's profit. The sum of construction cost and ancillary costs results in the building replacement cost (Eq. 1).

$$
R c=C c+A c
$$

The accounting principles state that land improvements are subject to deterioration and obsolescence, while the land is not. Therefore, the land value $(L v)$ should be extrapolated before applying depreciation, which refers only to the improvement value. This is the aim pursued in the third phase. The breakdown of the relationship between land value and improvement value has been recognized among the prominent topics in real estate valuation research (KRAUSE, BITTER 2012). While developing the DRC method, it is possible to exploit the concept of land leverage $(L l)$ as brought to the fore by BOSTIC et al. (2007). $L l$ is the "ratio of land value to overall value" (BOSTIC et al. 2007, p. 184, BOURASSA et al. 2011) and refers to the proportional (or fractional) apportionment approach (HENDRIKS 2005, ÖZDILEK 2012) (Fig. 2). According to the notations above, the overall value of 
a property $(O v)$ may be defined as the sum of land value and replacement cost:

$$
O v=L v+R c
$$

Hence, the land value is the difference between the overall value and replacement cost:

$$
L v=O v-R c
$$

In turn, the land value may be expressed as a function of the property's total value:

$$
L v=L l \cdot O v
$$

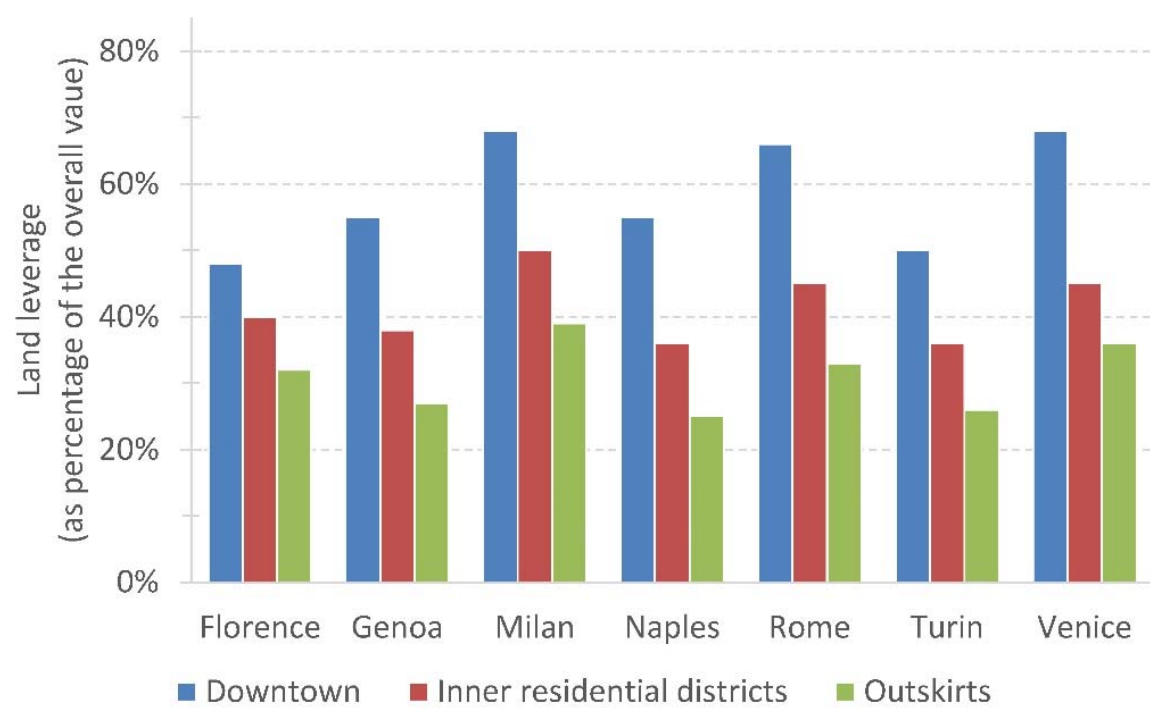

Fig. 2. Examples of land leverage in a selection of Italian cities. Source: Consulente Immobiliare, a technical journal connected to the financial newspaper Il Sole 24 Ore, No. 1000, 15 June 2016.

It goes without saying that the overall value is still unknown at this stage, while the replacement cost stems from the previous stage. Nonetheless, by substituting Eq. (2) in Eq. (4), we get that:

$$
\begin{gathered}
L v=L l \cdot(L v+R c) \\
L v=(L l \cdot L v)+(L l \cdot R c) \\
L v-(L l \cdot L v)=(L l \cdot R c) \\
L v \cdot(1-L l)=(L l \cdot R c) \\
L v=L l \cdot R c /(1-L l)
\end{gathered}
$$

Therefore, the land value may be extrapolated from the estimated replacement cost by multiplying it by the land leverage and, finally, dividing by the one's complement of the same land leverage ratio. Although perfectly consistent from a purely mathematical perspective, the above Eqs. (5)-(9) give rise to a paradox: land value turns out to be inferred from the building cost, but the former is actually independent of the latter, being mostly influenced by characteristics such as location, proximity to amenities, accessibility, and so forth (ÖZDILEK 2011). Other related issues are discussed later.

The fourth stage is devoted to the depreciation of the replacement cost, according to the deterioration and obsolescence characterizing the built components of the property. Practitioners are used to dealing with this issue by approximating the residual value, expressed by a coefficient $(K)$, through a linear function of useful economic life $(U l)$ and residual life $(R l)$ :

$$
K=(U l-R l) / U l
$$

The above equation relies on the premise that deterioration and obsolescence grow as time passes. After all, some literature argues that building age is among the main determinants of structural adequacy (KUTTY 1999). The useful life of a building may be quite difficult to estimate. Several studies on this topic have been carried out so far, allowing us to benefit from various kinds of data inventories 
(STONE 1980; GOTTFRIED 2003; MANGANELLi 2011). Eq. (10) is commonly referred to as the age/life method (also straight-line method), and it sums up the accrued depreciation providing a lump-sum deduction (APPRAISAL INSTITUTE 2013). It deserves mentioning that non-linear depreciation functions are also available and they have been long since discussed by accountants (CARMAN 1956). Out of these let us, for instance, consider the following, which is widely adopted in Italy (see UEC 1963, p. 55, and FORTE, DE ROSSI 1974, p. 205):

$$
K^{\prime}=\left[(K \cdot 100+20)^{2} / 140-2.86\right] / 100
$$

The depreciated cost $(D c)$ is then given by the following equations, where $D$ and $D^{\prime}$ represent the share of replacement cost remaining after the depreciation:

$$
\begin{gathered}
D=1-K \\
D^{\prime}=1-K^{\prime} \\
D c=R c \cdot D \\
D c=R c \cdot D^{\prime}
\end{gathered}
$$

The fifth stage concludes the estimation process. It recaps the calculations produced during the previous steps, leading to identify the replacement value $(R v)$ as the sum of the depreciated cost and the land value:

$$
R v=D c+L v
$$

\section{Background literature on methodological issues}

\subsection{Replacement cost as market value?}

DRC involves several significant issues. The first problem concerns the suitable placement of the method among the previously discussed valuation bases, and the kind of result it may provide. Although there seems to be no doubt that DRC does not belong to the market value basis, the chance of it producing a kind of market value is debated. FRENCH, GABRIELLI (2007) point out that, in the UK, the result of DRC is firmly considered different than market value. Conversely, outside the UK and especially in continental Europe, appraisers are easily prone to make use of DRC to derive the market value. For instance, the "localization differentiation approach" adopted in Slovakia and discussed by WALACIK et al. (2013) essentially resembles a DRC. The International Valuation Standards (IVSC 2016) tend to get close to the latter setting, and even the UK Royal Institution of Chartered Surveyors (RICS 2013) moves toward its adoption. WYATT $(2009,2013)$ extensively addresses this issue. The author tries to prove wrong the assumed linkage between DRC and market value, offering several arguments against it. In a competitive market, the demand and supply forces lead to an equilibrium such that the price (value-in-exchange, the amount asked, offered, or paid for a good or service) is closely related to the cost (the expense required to produce a good or service). Instead, a less-than-competitive market wherein one or few entities are predominant, see the cases of monopoly and oligopoly - is usually characterized by a gap between price and cost (which, incidentally, gives rise to the occurrence of extra-profits). Because the DRC method is most likely to be used to estimate property belonging to non-competitive markets - namely, specialized properties, not commonly traded, and without close substitutes - the assumption that cost and price converge may be misleading (Fig. 3). In short, a competitive market is required to reliably equate cost and price, but the lack of competitiveness is precisely the reason why we make use of DRC.

\subsection{Land value versus building value}

A second issue pertains to the distinction between land value and building value. Both land and construction constitute a property from a physical perspective, but are their respective values clearly discernible? WHIPPLE (1995) contends they are merged into a unique utility flow, so even the assumption that the relationship is additive may turn out arbitrary. Although evocative, the inseparability thesis as supported by HENDRIKS (2005) is not fully convincing, because many land value determinants are recognizable before a building is constructed and persist after its decommission (ÖZDILEK 2011). Moreover, even though the above criticism appears well-founded, the 
split of land and building values represents an unavoidable task in many fields. For instance, publiclyowned land is sometimes granted to a private developer under the framework of a long-term ground lease (also known as building lease or surface right). This entails the need to keep separate the land and building values for accounting purposes. A most common example is as follows. Companies are required to record the value of tangible assets on their balance sheets. Nevertheless, in many countries, they may write off buildings and improvements for tax purposes, but not the land value. Therefore, they need to distinguish the two value components, and appraisers are usually asked to do this. Accordingly, the International Accounting Standard No. 16 (s. 58) states that "Land and buildings are separable assets and are accounted for separately, even when they are acquired together. [...] land has an unlimited useful life and therefore is not depreciated. Buildings have a limited useful life and therefore are depreciable assets."

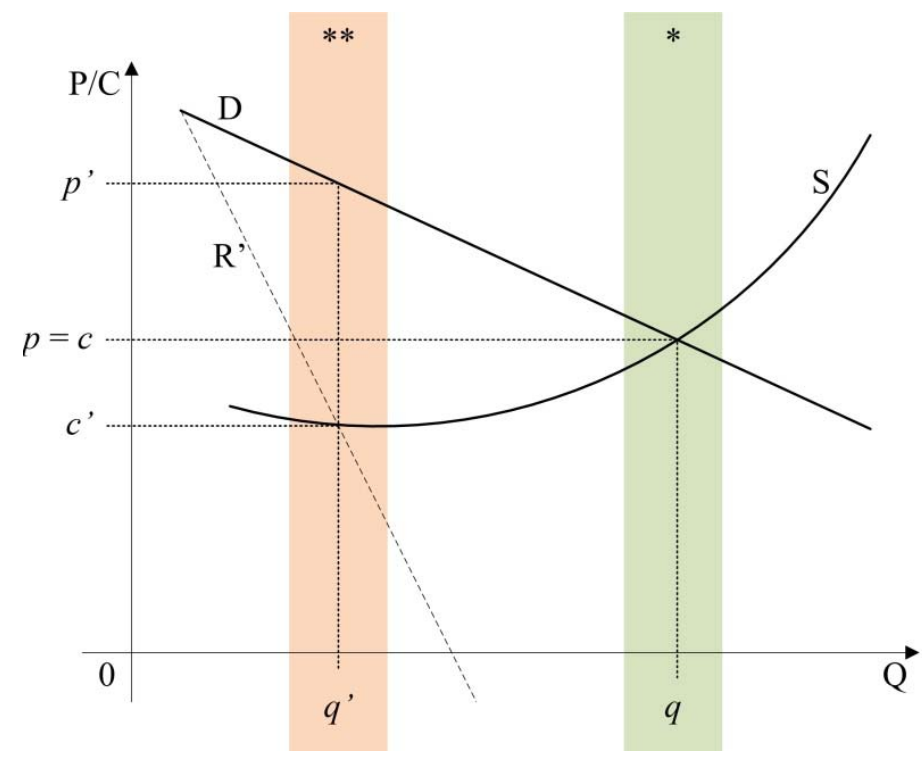

D: Demand curve

S: Supply curve

R': Marginal revenue

P/C: Price/Cost

Q: Quantity

*: Equilibrium in competitive markets

**: Equilibrium in less-thancompetitive markets

Fig. 3. Equilibrium in competitive and less-than-competitive markets. Source: own study.

The procedure of extraction and apportionment of the land value underlying to previous Eqs. (4)(9) is affected by a certain degree of subjectivity. It results in an indirect estimation, whose legitimacy is partly challenged by literature. Due to the need to rely on a set of assumptions, it may cause a lack of accuracy and uniformity (JOWSEY 2011; BOYD, BOYD 2012). Therefore, it is preferred as a rule of thumb and mainly accepted in the absence of market comparables (ÖZDILEK 2012).

The issue is further complicated by the concept of a notional replacement site. Literature introduces this reference on the economic premise that a rational developer is prone to buy the less expensive land parcel suitable for a certain use (WYATT 2013). In the case of old manufacturing buildings now enclosed in central urban fabrics, for instance, the said rational developer would prefer a modern equivalent location, such as a peripheral site.

\subsection{Deterioration and obsolescence}

A third issue involves the source of depreciation in the building, which reverberates in the lessening of "both its investment value to the owner and utility value to the occupier" (WYATT 2013, p. 173). The buildings lose part of their value during the course of time due both to deterioration and obsolescence. The two phenomena are different in nature (Fig. 4). Deterioration is a continuous physical process depending on the use to which a property is put. It may be foreseen, kept under control, and counteracted by day-by-day maintenance tasks until the building performance falls so low as to require refurbishment (see $a, b$, and $c$ in Fig. 4). On the contrary, obsolescence is a non-linear, irregular, and discontinuous socio-economical process expressing changes in consumers' needs, as well as in the regulations establishing requirements and standards (see $d, e$, and $f$ in Fig. 4). In short, obsolescence is a discrete process, which "will strike at irregular intervals and possibly affects all buildings in a particular sector, irrespective of their age", according to MANSFIELD, PINDER (2008, p. 200). More to the point, literature gathers the common causes of obsolescence in a few sets: technological changes (affecting the functional features), shifts in consumers' expectations (affecting their appreciation), and 
regulatory changes (affecting minimum requirements). For an in-depth taxonomy and an extensive review of the nature of underlying causes, see GROVER, GROVER (2015). In the introductory section of their article, the same authors provide a concise but fitting explanation of what obsolescence due to changing consumer behavior means. It gets to the heart of the matter by stating that we may observe impairment charges on the balance sheet value of properties no longer reflecting the profitability expectations, without any correlation with their physical deterioration.

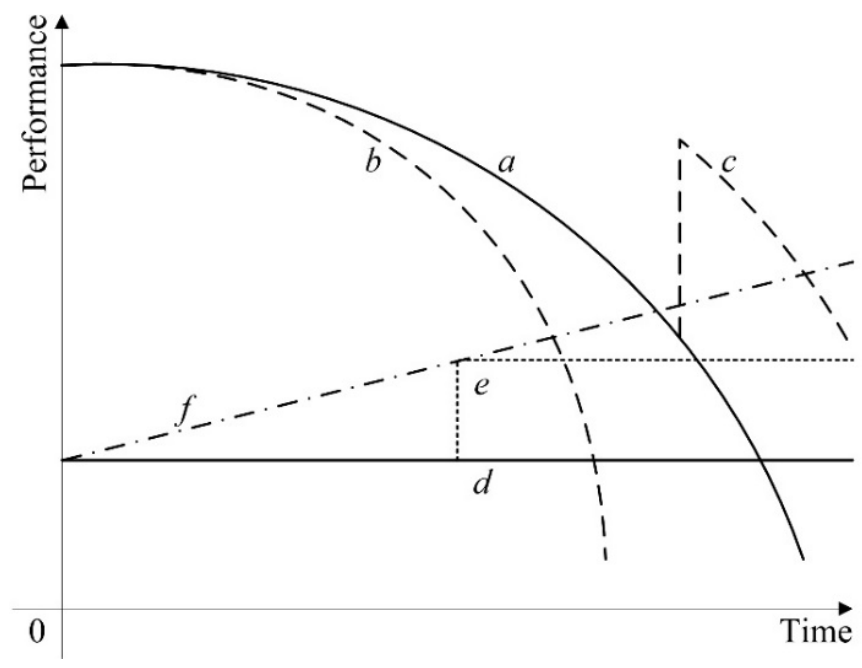
a: aging with ordinary maintenance
$b$ : aging without ordinary maintenance
$c$ : aging with refurbishment
$d$ : minimum acceptable performance
$e$ : minimum performance with strengthened standards
$f$ : consumers' increasing expectations

Fig. 4. Comparison between deterioration and obsolescence. Source: authors' elaboration based on ISELIN, LEMER (1993, pp. 11-29).

The occurrence of obsolescence, as well as its progression, is hardly predictable, thus maintenance is mostly unfit to slow it down. Nevertheless, the more flexible the building layout is, the more easily obsolescence can be contrasted (BAUM 1991). In brief, "economic depreciation is the dual of physical deterioration" (HULTEN, WYKOFF 1980, p. 99). As a consequence, the ratio between residual and useful life (Eq. 10) may reliably approximate the depreciation stemming from deterioration (also known as physical obsolescence) (WYATT 2013), while the depreciation engendered by obsolescence is more difficult to assess (MANSFIELD, PINDER 2008) since it involves the use of productivity measures (BOYD, BOYD 2012).

MANSFIELD, PINDER (2008) look through the concepts of economic and functional obsolescence. Properties become economically obsolete due to shifts in the site's appreciation, according to changes in its locational features (e.g., a mall that loses customers when a new highway diverts traffic flows). Moreover, properties may undergo functional obsolescence due to changes in consumers' needs, leading, in the end, to the underutilization or abandonment of hardly-transformable constructions (e.g., traditional stable barns complementary to large farmsteads are no longer used for agricultural purposes in the Po Valley, Northern Italy; archival spaces in office buildings are made obsolete by the transition toward paperless working environments; retail shops and their business model are challenged by the sharp growth of online shopping). Beyond the semantic distinction, there are significant implications for the estimation process: economic obsolescence impairs property value, but the functional one may simply reset the residual value of the construction to zero.

\section{Proposal for a method's variant}

\subsection{Depreciated Replacement Cost variant}

Regardless of the methodological issues discussed in the previous sections, DRC is ever more widespread in the professional practice because of operational reasons, not least the lack of transaction data due to the real estate market recession (COPIELLO et al. 2017). Since there are situations wherein making use of DRC is unavoidable, we aim to discuss several improvements to be brought to the method. Although they do not fully solve the issues above, they help to sharpen the estimation results. The three following sections discuss each of the cornerstones which the method's variant relies on. In summary, they are: a) partition of the replacement cost into its fundamental components; b) formulation of separate depreciation curves; c) definition of a complex depreciation function. These 
improvements aim to transfer into practice the concept that deterioration and "obsolescence may affect different parts of the building at different rates" (WYATT 2013, p. 175). Moreover, they are inspired by the comprehensive work by MANGANELLI (2011) and benefit from its methodological setting.

\subsection{Partition of replacement cost}

The parts of a building differ from each other in terms of cost, useful life, the deterioration process, and so forth. Therefore, let us leave aside the construction as a whole and consider the cost of each part as a first step to improving the method. To the extreme, every building material has its own characteristics. Nevertheless, we aim to pursue an equilibrium in the trade-off between the need to summarize and the will to particularize. To that end, the tripartition between structure, finishes, and installations appears to be a suitable solution. It is made possible by the wide availability of data at this level of detail. Particularly, we refer to building price lists that convey cost information organized according to construction typologies. An excerpt from MILAN BOARD OF ENGINEERS AND ARCHITECTS (2014) is presented in Figure 5.

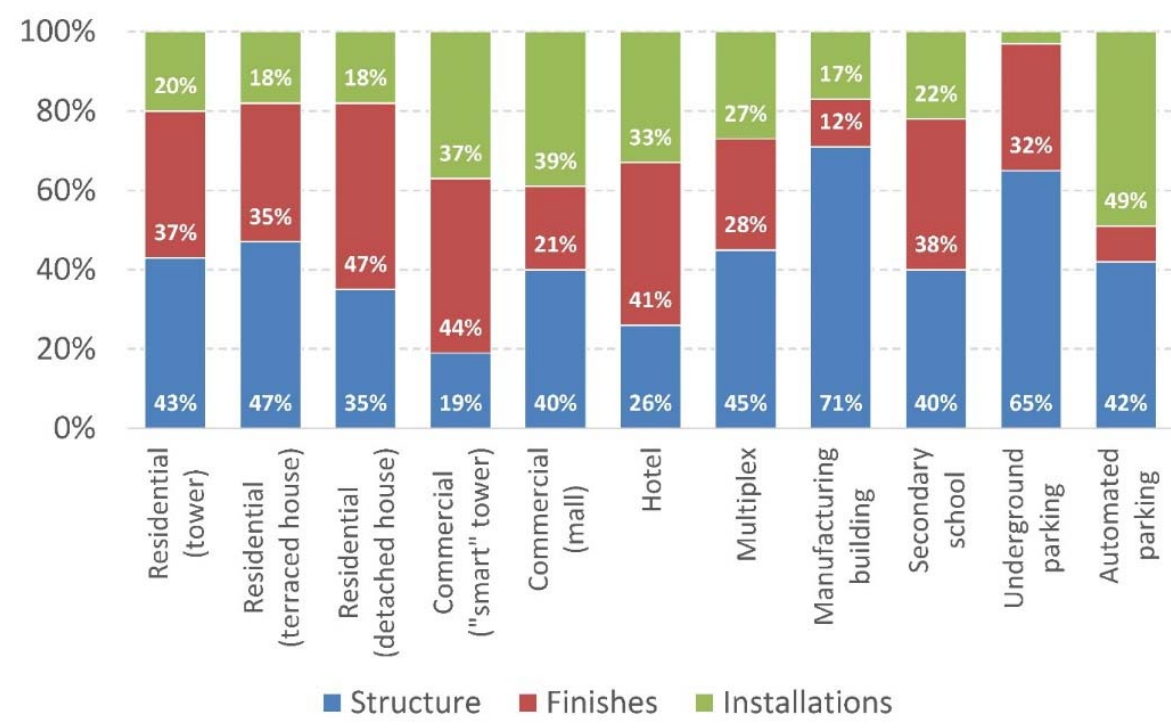

Fig. 5. Comparison of cost ratios for reference buildings belonging to various typologies. Source: authors' elaboration based on MILAN BOARD OF ENGINEERS AND ARCHITECTS (2014).

The graph reveals the importance of the first improvement to the method we are discussing. The residential building typologies are characterized by a rather stable apportionment of the construction costs, although some noteworthy differences occur, such as the higher incidence of finishes in the detached houses. When we turn to consider non-residential building typologies, we face a much more variegated array of data. For instance, the weight of the installations is close to $40 \%$ in office towers and malls, and rises to nearly $50 \%$ in automated parking. Similarly, another outstanding feature is represented by the prevailing role played by the structures in manufacturing buildings, as well as in underground parking. In the following variant validation, we will use the data concerning a semidetached house as presented in Table 2.

\subsection{Separate depreciation curves}

The above discussion paves the way to the second enhancement of the method. The replacement costs of the structure, finishes, and installations may be separately depreciated by estimating their appropriate useful life, as well as their residual life according to the time of development or refurbishment. Some technical handbooks provide valuable suggestions on which to base estimates and assumptions in this branch (Tab. 3). The figures presented in MANGANELLI (2011) have the merit of improving the awareness about an interesting dichotomy (Tab. 4). On the one hand, the buildings are mainly characterized by long-lasting structural components. Thus, for instance, a reinforced concrete structure or a load-bearing masonry may remain in use for more than a century, even if they are subject to little or no maintenance. On the other hand, many finishes and installations are 
characterized by a shortened useful life; hence, they require replacement - or, at least, restoration more often.

Table 2

Cost incidence for a reference building

\begin{tabular}{|c|c|c|c|c|}
\hline Cost item & $\begin{array}{c}\text { Cost } \\
\text { incidence }\end{array}$ & Structure & Finishes & Installations \\
\hline Excavation works & $1.1 \%$ & $1.1 \%$ & & \\
\hline Reinforced concrete frame & $28.0 \%$ & $28.0 \%$ & & \\
\hline Roofing & $6.5 \%$ & $6.5 \%$ & & \\
\hline External walls & $6.4 \%$ & $6.4 \%$ & & \\
\hline Internal walls & $3.2 \%$ & $3.2 \%$ & & \\
\hline Vents and chimneys & $1.1 \%$ & $1.1 \%$ & & \\
\hline Plastering & $9.7 \%$ & & $9.7 \%$ & \\
\hline Marble doorsteps and windowsills & $4.3 \%$ & & $4.3 \%$ & \\
\hline External doors and windows & $4.2 \%$ & & $4.2 \%$ & \\
\hline Internal doors & $3.2 \%$ & & $3.2 \%$ & \\
\hline Flooring & $9.7 \%$ & & $9.7 \%$ & \\
\hline Metal work finishes & $2.2 \%$ & & $2.2 \%$ & \\
\hline Heating system & $6.4 \%$ & & & $6.4 \%$ \\
\hline Water and sanitary system & $8.6 \%$ & & & $8.6 \%$ \\
\hline Wiring & $5.4 \%$ & & & $5.4 \%$ \\
\hline Total & $100.0 \%$ & $46.3 \%$ & $33.3 \%$ & $20.4 \%$ \\
\hline
\end{tabular}

Source: authors' elaboration based on MILAN BOARD OF ENGINEERS AND ARCHITECTS (2014).

Useful life and periodic maintenance

\begin{tabular}{lrrr}
\hline & Structure & Finishes & Installations \\
\hline Economic life without maintenance & 60 & 25 & 25 \\
Periodic maintenance intervals & 15 & 10 & - \\
Lengthening of life due to periodic maintenance & 175 & 60 & - \\
\hline
\end{tabular}

Source: authors' elaboration based on GOTTFRIED (2003).

\subsection{Complex depreciation function}

The complex depreciation function we are proposing lends itself to be expressed as follows. Let us consider $i=1, \ldots, n$ building elements and $j=1, \ldots, m$ intervention years, including the initial construction works and the subsequent refurbishments (with $m$ equal to 1 for each building element that has never been refurbished). Let us say $w_{i}$ is the economic weight of each building element, i.e. the ratio between its cost and the overall construction cost. $Y_{i j}$ denotes the array of each intervention year $j$ on each building element $i$. Moreover, $A y$ is the appraisal year, while $U l_{i}$ represents the estimated useful life, as in previous Eq. (10), now differentiated for each building element $i$. A significant portion of the depreciation function is given by:

$$
K^{\prime \prime}=\sum_{i=1}^{n}\left(A y-Y_{i m}\right) / U l_{i} \cdot w_{i}
$$

Here, by resorting to a depreciation function that is the summation of distinct decay curves, we aim to take benefit from a secondary but not negligible aspect. Indeed, the relationship between age and depreciation may be better represented through various functional forms for each building element. Hence, the third cornerstone enables to define, for instance, a linear decay function for the finishes and installations while using a non-linear function for the structure (Fig. 6). Assuming that $i^{\prime}$ building elements (for instance, those belonging to the structure) are characterized by a non-linear depreciation as in previous Eq. (11), and that the other $n-i$ ' building elements (e.g. those belonging to finishes and installations) are linearly depreciated, the previous Eq. (17) may be rewritten as follows: 


$$
\begin{gathered}
K^{\prime \prime \prime}=\sum_{i=1}^{i^{\prime}}\left\{\left[\left(A y-Y_{i m}\right) / U l_{i} \cdot 100+20\right]^{2} / 140-2.86\right\} / 100 \cdot w_{i}+ \\
\sum_{i=i \prime \prime}^{n}\left(A y-Y_{i m}\right) / U l_{i} \cdot w_{i}
\end{gathered}
$$

where $i^{\prime \prime}=i^{\prime}+1$.

Table 4

Useful life and periodic maintenance

\begin{tabular}{lrrrrrrr}
\hline & \multicolumn{2}{c}{ Structure } & \multicolumn{3}{c}{ Finishes } & \multicolumn{3}{c}{ Installations } \\
& \multicolumn{1}{c}{$a$} & \multicolumn{1}{c}{$b$} & \multicolumn{1}{c}{$c$} & \multicolumn{1}{c}{ d } & \multicolumn{1}{c}{$f$} \\
\hline Economic life without maintenance & 120 & 60 & 5 & 15 & 33 & 15 \\
Periodic maintenance intervals & 50 & 40 & - & 5 & 10 & - \\
Lengthening of life due to periodic maintenance & 300 & 120 & 5 & 40 & 40 & 15 \\
\hline
\end{tabular}

$a$ : load-bearing masonry; $b$ : reinforced concrete structure; $c$ interior painting; $d$ : exterior wooden frames; $e$ : heating system; $f$ : air conditioning system.

Source: authors' elaboration based on MANGANELLI (2011).
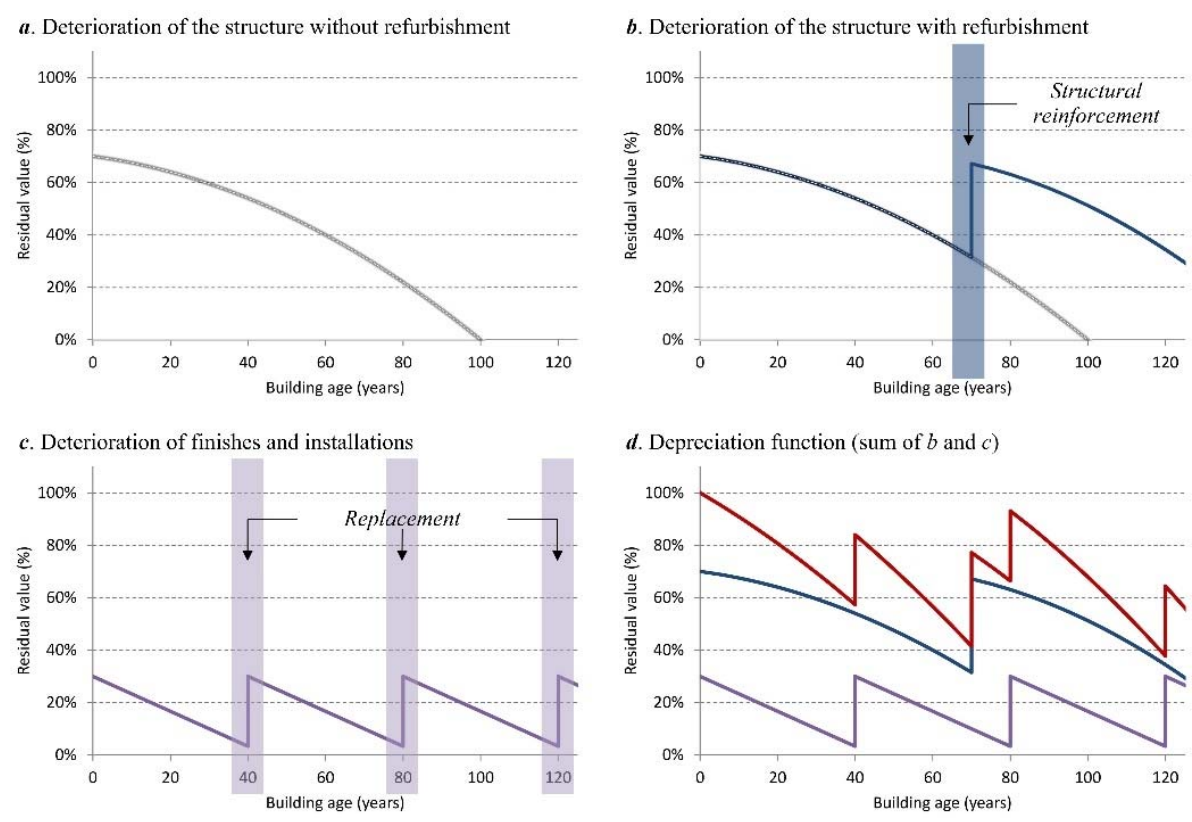

Fig. 6. Complex depreciation function. Source: own study.

The depreciation function we propose deals solely with the issue of deterioration. In fact, we consider that the obsolescence issue should be treated differently. After all, literature expresses the awareness that addressing the obsolescence according to a time basis represents a methodological bias (GROVER, GROVER 2015). The value of an obsolete property may be better identified using the income approach, and then performing a discounted cash flow analysis according to its highest and best use (Fig. 7). It means that the cost approach and the DRC method should be bound to cases of properties whose existing use still gets market appreciation.

\subsection{Validation of the method's variant through a case study}

To perform a validation of the proposed variant, we focus on a property located in a peripheral town of the province of Venice, Northern Italy. The property has been recently appraised by the Italian Revenue Agency during a tax inspection. Because of its suburban location - not to mention the weakness of the real estate market - not a single comparable building was found by analyzing the recent sales. Therefore, the DRC method was opted for. The result was challenged by the property owners, who argued that the method was misapplied. More precisely, the owners asked the agency to revise the appraisal in accordance with the actual deterioration of the building elements. Under this framework, the following analysis aims to quantify the gap with respect to a standard application of the DRC method. 


\section{S sciendo}

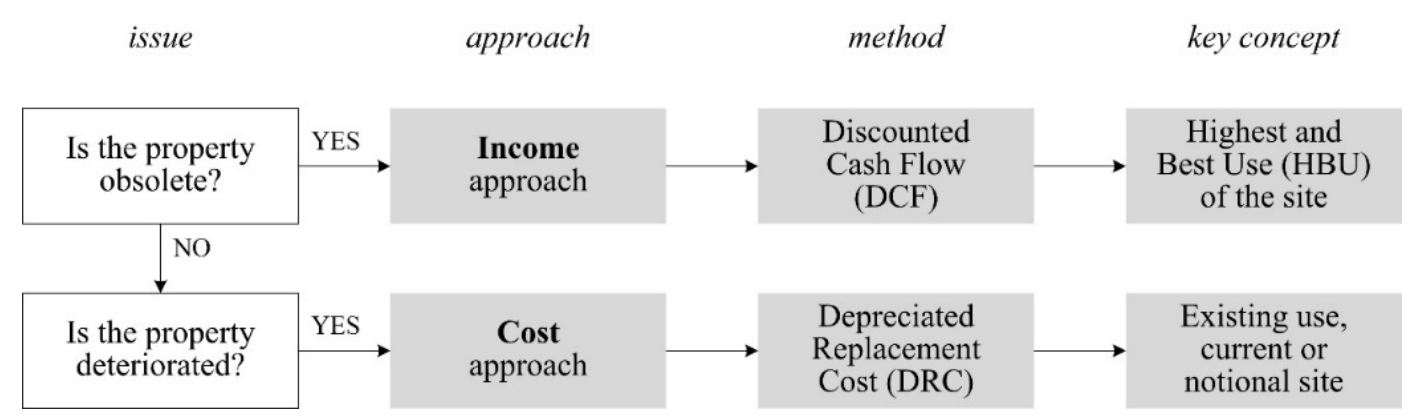

Fig. 7. Application limits of the DRC variant. Source: own study.

The case study consists of a three-storey building, which occupies most of its small land plot. An inspection of building permits issued by the Municipal Authority enables to identify the timeline of the relevant interventions. Construction works were carried out during the forties and the building was first renovated in 1962 (Fig. 8, left). Although the details about the performed works are poor, it is possible to argue they affected finishes and installations, as well as the structure. The building was further refurbished in 2005 (Fig. 8, right), with the purpose of transforming the former dwelling into six semi-independent one-room flats to be managed according to the business model of an apart hotel. Nevertheless, the last works have kept the structure unchanged, being focused mainly on creating internal partitions, renewing the finishes, and adding the required installations.

In accordance with the above framework, Figure 9 shows the significant timeline for appraisal purposes. The useful life of 60,20 , and 10 years for the structure, the finishes, and the installations, respectively, has been assumed by the Revenue Agency. The appraisal date is June 23, 2014. Therefore, the residual life is 8 years for the structural elements, 11 years for the finishes, and 1 year for the installations.
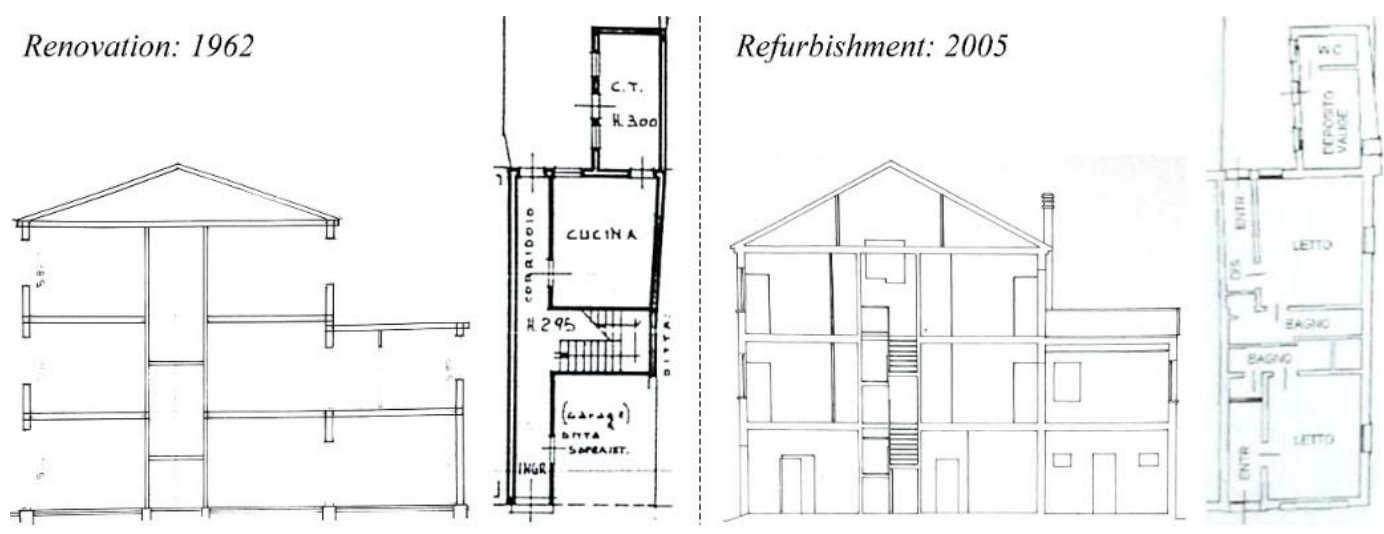

Fig. 8. Case study: vertical sections and ground floor plans. Source: building permits and annexes.

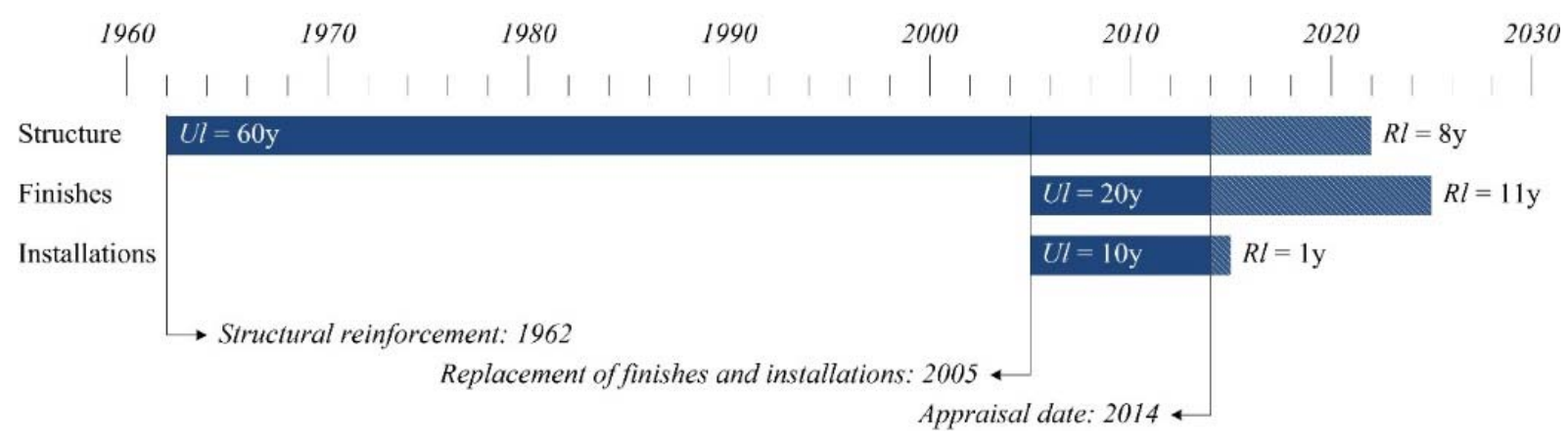

Fig. 9. Case study: significant timeline. Source: own study.

Initially, the estimation process focuses on the appraisal of the construction cost, the ancillary costs, and the land value (Tab. 5), according to phases 1 to 3 represented in Figure 1 above. Afterwards, the DRC method is implemented according to its basic formulation using a single function to compute the 
depreciation (Tab. 6). The residual life is estimated starting from the last renovation works, which were carried out in 2005 (Fig. 9), regardless of the affected building components. On the contrary, the variant proceeds with the apportionment of the construction cost according to the tripartition between structure, finishes, and installations. The building elements are then depreciated separately, by distinguishing both their useful and residual life (Tab. 7): this makes it possible to take into account that the most recent renovation works were limited to finishes and installations, while the life of the building structure should be counted starting from works carried out during the early sixties.

Table 5

DRC: phases 1-3 according to the scheme in Figure 1

\begin{tabular}{|c|c|c|c|c|c|c|c|c|}
\hline \multirow[b]{2}{*}{ Construction cost } & \multicolumn{2}{|c|}{ Quantity } & \multicolumn{2}{|c|}{ Unit value } & \multicolumn{2}{|c|}{ Incidence } & \multicolumn{2}{|c|}{ Total } \\
\hline & $\mathrm{a}$ & 100 & $\mathrm{~b}$ & 900 & & & $c=a \cdot b$ & 90,000 \\
\hline Ancillary costs & & & & & $\mathrm{d}$ & $15 \%$ & $e=c \cdot d$ & 13,500 \\
\hline Replacement cost & & & & & & & $\mathrm{f}=\mathrm{c}+\mathrm{e}$ & 103,500 \\
\hline Land value & & & & & $\mathrm{g}$ & $10 \%$ & $\begin{array}{r}h=(f \cdot g) / \\
(1-g)\end{array}$ & 11,500 \\
\hline
\end{tabular}

Source: own study.

DRC: basic method, phases 4-5 according to the scheme in Figure 1

\begin{tabular}{|c|c|c|c|c|c|}
\hline \multirow[b]{2}{*}{ Useful life } & \multirow[t]{2}{*}{ Quantity } & Unit value & Incidence & \multicolumn{2}{|c|}{ Total } \\
\hline & & 60 & & & \\
\hline Residual life & & 51 & & & \\
\hline Depreciation & & & $k=1-j / i \quad 15 \%$ & & \\
\hline Depreciated cost & & & & $\begin{array}{r}\mathrm{l}=\mathrm{f} \cdot(1- \\
\mathrm{k})\end{array}$ & 87,975 \\
\hline Replacement value & & & & $\mathrm{m}=1+\mathrm{h}$ & 99,475 \\
\hline
\end{tabular}

Source: own study.

The strength of the proposed variant is shown by the difference in the results. Beyond the absolute value, the basic method provides a rough estimate. Incidentally, it is worth noting that also the traditional DRC approach lends itself to consider the effect of maintenance works carried out over the years. However, being unable to divide the building into its functional parts, the valuation process is not as accurate as in the discussed variant. Here, the gap between the variant and the basic method overcomes the threshold of 60 percent. It is worth mentioning that this gap does not necessarily lessen if the last works on the building date back to the far past. Some simulations provide evidence for this claim. Let us suppose that the last renovation works on finishes and installations were carried out in various years during the period 1965-2005. The basic version of the method provides a replacement value that increases proportionally according to the year of these renovation works. In the variant, on the other hand, the same works exclusively affect the residual life of finishes and installations, which are characterized by a short useful life. Therefore, the same works lead to an increase of the replacement value only when carried out in the not so distant past (Fig. 10).

\section{Conclusions}

In this article, we deal with the need to improve the DRC method given the non-negligible role it plays in the real estate appraisal practice. Following the methodological setting proposed in recent literature, here, we outline a variant of the method based on three cornerstones: adoption of a tripartite replacement cost, estimation of separate depreciation curves, and formulation of a complex depreciation function. 
DRC: variant, phases 4-5 according to the scheme in Figure 1

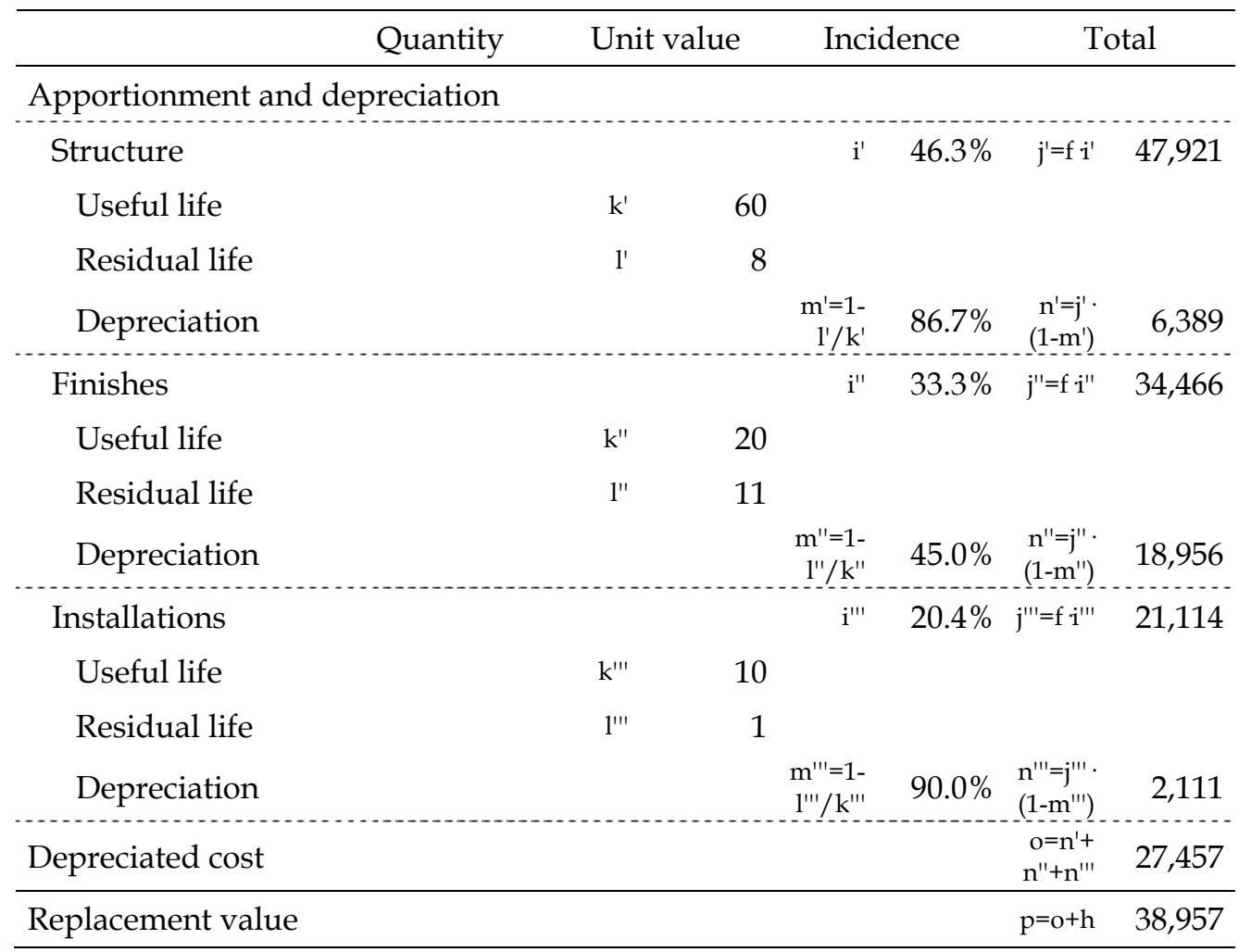

Source: own study.

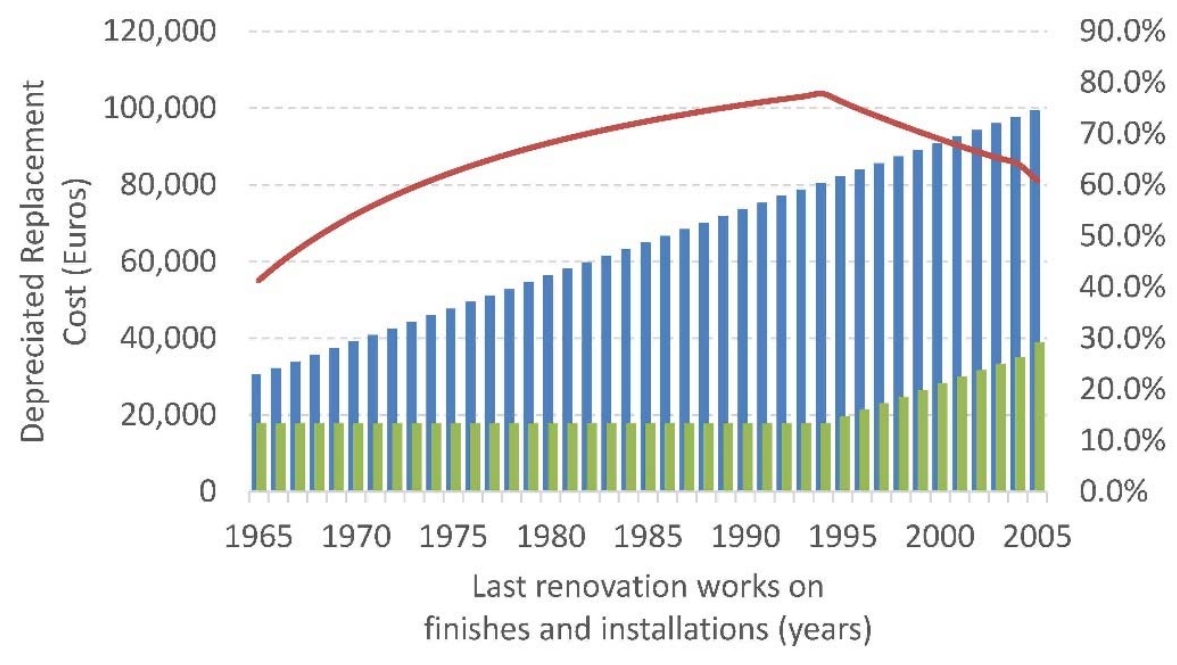

Results: basic method Results: variant - Results: gap

Fig. 10. Basic method and variant: gap in the results. Source: own study.

It is however possible to notice some limitations which need to be further addressed. Firstly, the depreciation rate requires additional studies. The research on why and how buildings lose value as they age is crucial in order to ensure that the depreciated cost has a direct link with the worth-inexchange as expressed by the market. Secondly, we should be aware of the fact that, beyond physical deterioration, both the basic method and the proposed variant are likely to fail to reflect economic obsolescence, because its underlying causes do not depend strictly on time. When obsolescence prevails on the deterioration, other methods are better suited to the appraisal issue. 
That said, the validation of the variant on a case study proves its satisfactorily performance and usefulness in pursing the aim of improving the appraisal.

\section{Acknowledgements}

The author would like to thank the property owners for their permission to use the case study materials. The data used to validate the variant, although reliable, are partly fictitious due to reasons of privacy, particularly those concerning the building dimension, the unit cost of construction, and the land leverage.

\section{References}

APPRAISAL INSTITUTE, 2013, The Appraisal of Real Estate, 14th Edition, Chicago.

BAUM A., 1991, Property Investment Depreciation and Obsolescence, London: Routledge.

Bostic R.W., LONGHOFER S.D., ReDFEARN C.L., 2007, Land leverage: Decomposing Home Price Dynamics, Real Estate Economics, No. 35 (2), pp. 183-208.

BOURASSA S.C., HOESLI M., SCOGNAMiglo D., ZHANG S., 2011, Land Leverage and House Prices, Regional Science and Urban Economics, No. 41 (2), pp. 134-144.

BOYD T., BOYD S., 2012, Valuing the Land Component of Improved Investment Property, Journal of Property Investment \& Finance, No. 30 (4), pp. 338-353.

CARMAn L.A., 1956, Non-Linear Depreciation, The Accounting Review, No. 31 (3), pp. 454-491.

COPIELlo S., 2016, Economic Implications of the Energy Issue: Evidence for a Positive Non-linear Relation between Embodied Energy and Construction Cost, Energy and Buildings, No. 123, pp. 59-70.

Copiello S., Cosmi V., STANGHellini S., 2017, Appraisal of Manufacturing Buildings through the Depreciated Replacement Cost Approach, in STANGHELLINI S., MORANO P., BOTTERO M., OPPIO A. (Eds.), Appraisal: From Theory to Practice, Cham: Springer, pp. 15-26.

CROSBY N., DeVANEY S., LAW V., 2011, Markets benchmarking and valuation issues in measuring depreciation for European office markets, Journal of European Real Estate Research, No. 4 (1), pp. 7-28.

DAVIS LANGDON \& EvereSt, Spon's European Construction Costs Handbook, Third Edition, Oxford: Taylor \& Francis, 2000.

Dutch Association OF Cost Engineers, 2015, Price Booklet, 31st Edition, Nijkerk.

Forte C., De Rossi B., Principi di economia ed estimo, Milano: Etas, 1974.

FrenCH N., GABRIELLI L., 2007, Market Value and Depreciated Replacement Cost: Contradictory or Complementary?, Journal of Property Investment \& Finance, No. 25 (5), pp. 515-524.

GOTTFRIED, A. (Ed.), La qualità edilizia nel tempo, Milano: Hoepli, 2003.

Grover R., Grover C., 2015, Obsolescence - a Cause for Concern?, Journal of Property Investment \& Finance, No. 33 (3), pp. 299-314.

HENDRIKS D., 2005, Apportionment in Property Valuation: Should we Separate the Inseparable?, Property Investment \& Finance, No. 23 (5), pp. 455-470.

Hoesli M., MAcgregor B.D., 2000, Property investment: Principle and Practice of Portfolio Management, Essex: Pearson Education.

Hulten C.R., WYKOFF F., 1980, Economic Depreciation and the Taxation of Structures in United States Manufacturing Industries: An Empirical Analysis, in UsHER D. (Ed.), The Measurement of Capital. Chicago: University of Chicago Press, pp. 83-120.

ISELIN D.G., LEMER A.C. (Eds.), 1993, The Fourth Dimension in Building: Strategies for Minimizing Obsolescence, Washington D.C.: National Academy Press.

IVSC, 2013, International Valuation Standards 2013 Framework and Requirements, London.

IVSC, 2016, IVS 104: Bases Of Value, London.

JOWSEY E., 2011, Real Estate Economics, Basingstoke: Palgrave Macmillan.

KRAUSE A.L., BITTER C., 2012, Spatial Econometrics, Land Values and Sustainability: Trends in Real Estate Valuation Research, Cities, No. 29, pp. S19-S25.

KuTTY N.K., 1999, Determinants of Structural Adequacy of Dwellings, Journal of Housing Research, No. 10 (1), pp. 27-42.

LangdON \& SeAH, 2016, Construction Cost Handbook - China \& Hong Kong 2016, Hong Kong.

MANGANELli B., 2011, Il deprezzamento degli immobili urbani, Milano: FrancoAngeli.

MANSFIELD J.R., PINDER J.A., 2008, "Economic" and "Functional" Obsolescence: Their Characteristics and Impacts on Valuation Practice, Property Management, No. 26 (3), pp. 191-206. 
Milan BoARd of Engineers AND ARChITECTS, 2014, Prezzi Tipologie Edilizie, Roma: Dei - Tipografia del Genio Civile.

Morgenson G., HARvey C.R., 2002, The New York Times Dictionary of Money and Investing, New York: Henry Holt and Company.

ÖZDILEK Ü., 2011, Land Value: Seven Major Questions in the Analysis of Urban Land Values, American Journal of Economics and Sociology, No. 70 (1), pp. 30-49.

ÖZDILEK Ü., 2012, An Overview of the Enquiries on the Issue of Apportionment of Value Between Land and Improvements, Journal of Property Research, No. 29 (1), pp. 69-84.

RICS, 2013, RICS Valuation - Professional Standards, London.

STONE P.A., 1980, Building Design Evaluation. Cost in use, London: Spon Ltd.

UEC, 1963, La valutazione delle aziende, Milano: Etas-Kompass.

WAlaciK M., Grover R., AdAmUScin A., 2013, Valuation Systems in Poland, Slovakia and the United Kingdom - Comparative Study, Real Estate Management and Valuation, No. 21 (4), pp. 75-86.

WhIPPLE R., 1995, Property Valuation and Analysis, Sydney: The Law Book Company.

WYATT P., 2009, Replacement Cost and Market Value, Journal of Property Investment \& Finance, No. 27 (6), pp. 593-602.

WYATT P., 2013, Property Valuation, Second Edition, Oxford: Wiley-Blackwell. 